\title{
Study on Reform of Innovative Talents Training of English Majors in Independent Colleges under Cross-border E-commerce
}

\author{
Liu Lei \\ School of Foreign Languages, Tianhe College of Guangdong Polytechnic Normal University, \\ Guangzhou510000, China. \\ 38650995@qq.com
}

Keywords: cross-border e-commerce; independent college; English major; innovative talent training

Abstract: The economic development needs more and more applied innovative talents for cross-border e-commerce English majors, and the talent training model is becoming more and more important. As a new model and new mechanism, the independent college is a supplement to the quantity of high-quality undergraduate education. The innovative talents training mode of English majors in independent colleges under cross-border e-commerce is studied, and the teaching level of English majors in independent colleges is improved. With the main characteristics of cultivating students' practical application ability and taking competence as the center to reform the talent model of cross-border e-commerce English teaching, the needs of economic development and the establishment of a harmonious socialist society is met, we should train English professionals in cross-border e-commerce. It is necessary to combine "educating people" with "cultivating talents", using brain and hands, infiltrating innovative education into the process of English teaching, guiding and arousing students' desire for knowledge, learning interest, providing conditions for the development of students' personality and creating environment. In the process of training English majors in independent colleges under cross-border e-commerce, it is necessary to flexibly apply teaching methods that conform to the abilities and knowledge characteristics of students, and pay attention to cultivating students' practical and hands-on abilities. According to the orientation of employment and the basis of learning, teaching should be carried out in different levels, the curriculum structure of innovative education should be constructed, the training mode of talents should be innovated constantly, the course system should be optimized, and the training of innovative talents in English major could be promoted and the quality of English teaching should be improved.

\section{Introduction}

The innovative talent training model of English majors in independent colleges under cross-border e-commerce is the knowledge, ability, quality structure and realization mode 
constructed by colleges and universities according to the talent training goals. It includes training objectives, ways of training, and setting of majors. The course system and teaching content, the teaching operation mechanism and the teaching organization form, namely what kind of person to train, how to train the human question. As a new model and new mechanism, independent college is a supplement to the quantity of quality undergraduate education and the type of undergraduate education. Independent college is the incubator of system innovation, it has become an important part and new growth point of higher education, and is the booster of the development of higher education $^{[1]}$. The main body of the students in independent colleges in China is the students with low scores in the college entrance examination. Although they have different learning bases, economic conditions, students' qualities and abilities, they still have low learning enthusiasm, unclear learning goals and insufficient learning motivation. Personality, emotional stability, lack of self-regulation and other weaknesses, in view of the independent college undergraduate applied cross-border English tradesman training goal positioning, combined with cross-border e-commerce English talent training specifications, on the basis of the characteristics of cross-border ecommerce English major, the innovation talent training system of cross-border ecommerce English major in independent colleges is studied ${ }^{[2]}$.

With the development of economy, the demand of applied and innovative talents for cross-border e-commerce English majors is increasing, and the training mode of talents is becoming more and more important. However, how to focus on their own reality, highlight their professional characteristics and cultivate applied innovative talents is a problem that the relevant parties are focusing on at present ${ }^{[3]}$. This paper expounds the connotation of applied innovative talents, the training objectives of applied innovative talents in cross-border ecommerce English majors and their realization measures, and analyzes the reform model of innovative talents training in English majors in independent colleges under cross-border ecommerce. This paper studies the innovative talents training mode of English majors in independent colleges under cross-border ecommerce, and improves the teaching level of English majors in independent colleges, with the main characteristics of cultivating students' practical application ability. To reform the talent model of cross-border e-commerce English teaching with competence as the center ${ }^{[4]}$. In the process of training English majors in independent colleges under cross-border ecommerce, we need to flexibly apply teaching methods that conform to the abilities and knowledge characteristics of students, and pay attention to cultivating students' practical and hands-on abilities. According to the orientation of employment and the basis of learning, teaching should be carried out in different levels, the curriculum structure of innovative education should be constructed, the training mode of talents should be innovated constantly, and the applied innovative talents needed by enterprises should be cultivated. And take this as the independent college English innovation talent training guiding ideology.

\section{Problems in Training Innovative Talents of English Majors in Independent Colleges under Cross-border E-commerce}

\subsection{Lack of multiple knowledge structure and difficulty in forming pluralistic thinking}

The formation of multiple thinking is the premise of innovation. To be creative and to discover ideas or phenomena that others cannot see or think of, multiple thinking is required. Multivariate thinking is not innate and requires multiple knowledge structures to make it possible. Only when we have more and more novel knowledge combinations can we not stick to the ideas and phenomena that have been accepted by most people, produce new ideas and find new phenomena. "These things are important to enlighten one's scientific innovation. Scientific innovation cannot be done by strict logical thinking. The innovative thought often starts from the image thinking, gets inspiration from the association of large span, and then verifies it with strict logic." Mr Qian Xuesen said of the 
knowledge structure ${ }^{[5]}$.

At present, more than $80 \%$ of college students in most independent colleges take the initiative to study English specialized knowledge, such as literature, music and other related English majors, except for their usual courses. The knowledge structure and learning process are relatively simple, and liberal arts students are unfamiliar with natural science. Science students do not understand English literature and art, which makes it difficult for liberal arts students to rationalize their thinking, while science students cannot visualize their thinking, and pluralistic thinking cannot be formed, they cannot connect unrelated things, they cannot think fluently. It cannot meet the requirements of English majors' innovative talents training ${ }^{[6]}$.

\subsection{Teaching system of Public English course needs to be reformed}

With the development of economy, the demands of social posts on graduates' knowledge, ability and quality are more diversified and concrete. The introduction and introduction of foreign advanced vocational education model has also been advocated by people. Under the cross-border e-commerce mode, the higher vocational talents training model has become more diversified because of the changes of posts and post groups. In the course of further strengthening the characteristics of higher vocational education, comprehensively deepening the teaching reform and improving the teaching quality, exploring the effective realization form of the mode of combining work and learning with talents, and striving to create the national exemplary higher vocational colleges and universities, Each major accelerates the innovation speed of the specialized personnel training mode, develops the order type training positively, adopts the task-driven, project-oriented, on-the-job practice and so on, which is beneficial to the enhancement of the students' ability, and actively creates the specialized curriculum which the teaching is integrated with. How to strengthen the training of students' vocational ability, shorten the distance between teaching and professional posts, how to adapt the public English course of independent college to the training mode of professional talents, and serve the specialty is our research topic, which is also our current problem to be solved urgently ${ }^{[7]}$.

\section{Connotation and Goal of English Creative Talents Training in Cross-border E-commerce in Independent Colleges}

\subsection{Connotation of innovative and practical talents in cross-border ecommerce English in independent colleges.}

Innovative and application-oriented, refers to the cultivation of talents not based on academic and research-oriented elite education, but on the orientation of popularized education based on technology to meet the actual needs of the vast number of employing units, facing the grass-roots level and the front line of production. Strengthen practical ability and practical ability, pay attention to not only intellectual education, but also the cultivation of non-intelligence factors ${ }^{[8]}$. Innovative talents refer to the fact that the talents trained are wider, more specialized and better able to learn independently than the applied talents trained in higher vocational and technical colleges, and not only have the skills to be competent for a certain occupation, but also have the ability to learn independently. And has applied knowledge to carry on the technical innovation and the technical secondary development ability. Therefore, the cultivation of applied innovative talents must be based on the comprehensive mastery of students' knowledge, take the cultivation of ability as the core, and take the improvement of comprehensive quality as the goal ${ }^{[9]}$. 


\subsection{Goal of Fostering innovative talents for English majors in Cross-border E-commerce}

As the transition period of China's entry into WTO ends, the degree of opening to the outside world is deepening continuously, which brings great opportunities for the development of foreign trade enterprises in our country. The quantity and quality of English majors in cross-border E-commerce are gradually improving. At present, import and export enterprises are faced with an increasingly mature market environment, with more and more collectivization, transnational, diversified management, business scope spanning many industries, business operations involving production, sales, services and other fields. English professionals in cross-border e-commerce are required to have a cross-industry, multi-domain, complex knowledge structure and the ability to adapt flexibly to complex environments and to innovate; on the other hand, the specific business of import and export trade is becoming more and more detailed and refined. The practical professional skills of cross-border e-commerce English majors are becoming more and more demanding ${ }^{[10]}$. Therefore, today's import and export enterprises need complex cross-border electricity merchants with comprehensive management ability, emergency innovation ability and practical professional skills. Take the Pearl River Delta region as an example, in 2017, the demand of import and export enterprises for cross-border electricity tradesman is about $9 \%$ of the total demand for graduate degree, and $75 \%$ of the total demand for undergraduate degree. At the same time, the demand for cross-border e-commerce talents is more inclined to have practical experience, and few enterprises are willing to recruit talents directly from college graduates. This shows that the talents trained in colleges and universities cannot meet the needs of foreign trade enterprises directly, at the same time, the ability of adaptation, adaptability and competitiveness of graduates need to be improved. In addition, according to Zhaopin recruitment statistics, mastering modern economic and trade, transportation and freight forwarding theory and skills, and with solid English skills, cross-border e-commerce applied innovative talent has become the most popular talent ${ }^{[11]}$.

\section{Measures to Foster Applied and Innovative Talents of English Majors in Cross-border E-commerce}

The talent training of cross-border e-commerce English majors in independent colleges should evolve with the development of China's foreign trade and economic cooperation, so as to keep pace with the times, therefore, in view of the current requirements of import and export enterprises for talents, The cultivation of practical and innovative talents in cross-border ecommerce English majors can be realized in the following aspects.

\subsection{To reform teaching methods}

The reform of teaching method is an eternal theme. The English major of cross-border e-commerce should focus on the cultivation of applied and innovative talents, change the traditional teaching mode of "system knowledge transfer as the core", "student-centered, teacher-led". The innovative education should be permeated into the English teaching process to guide and stimulate the students' desire for knowledge and interest in learning, to provide conditions for the development of students' personality and to create the environment. The learning consciousness of the students in independent colleges is generally not as good as that of the students in the parent school. Teachers should especially strengthen the research of teaching methods, combine research with teaching practice, and flexibly apply teaching methods that accord with the abilities and knowledge characteristics of the students. Pay attention to the cultivation of students' practical ability, carry out teaching according to employment orientation and learning foundation, encourage case teaching method, simulated training method, seminar course and bilingual teaching, 
Organizing some classroom discussion and writing for hot issues in economic life, organizing students to visit and study in import and export enterprises (field inspection method), and actually experiencing the operation process of cross-border e-commerce; Experts from various departments are invited to hold regular lectures on the latest developments and practical applications of international economy and trade. So that students can understand the development trend and practical operation steps of cross-border e-commerce in time, expand their knowledge, and lay a good foundation for the cultivation of applied innovative talents ${ }^{[12]}$.

\subsection{To construct the curriculum structure of innovative education}

As the basic link of university education, curriculum teaching is an important way for students to obtain knowledge and information directly. It plays a central role in shaping students' knowledge structure, ability and quality, and is the most direct way to achieve the goal of cultivation. In the aspect of curriculum setup and its system structure, we should constantly innovate the talent training mode and optimize the curriculum system from the requirements of strengthening the foundation, broadening the professional caliber, paying attention to improving the quality and cultivating the students' ability. The curriculum is designed to meet the needs of the society for the comprehensive quality of English majors in cross-border e-commerce, to expand and strengthen the deepening and expanding of professional knowledge of English for cross-border e-commerce, and to reduce the number of elective courses for non-cross-border e-commerce English majors, such as securities investment. Insurance introduction, enterprise strategic management, more foreign trade documents business, customs business, project management, logistics management and other courses. To create a curriculum structure of "certified courses", that is, according to the needs of the talent market for the knowledge, quality and ability structure of the personnel of customs declaration, documentaries, examiners, freight forwarders, consignors, export salesmen, etc., Corresponding to each industry qualification certificate to set up the corresponding curriculum, the real realization of "teaching, textual research, zero distance employment" three perfect combination $^{[13]}$.

In order to broaden the professional caliber and train the application-oriented creative talents with one specialty and many abilities, we should strengthen the mutual penetration and combination of related subjects in the course reform, break the boundaries of the disciplines, and carry on the knowledge horizontal connection and penetration. At the same time, in classroom teaching, teaching material is only the carrier of knowledge, not the whole of classroom knowledge. In the modern society with the rapid growth of knowledge, the knowledge recorded in the textbooks is far from keeping up with the progress of the times ${ }^{[14]}$. If students want to keep up with the pace of the times, they must introduce the world's advanced information in the field of cross-border e-commerce and expand their knowledge.

\subsection{To strengthen experiment and practice teaching}

Cross-border e-commerce is a kind of economic activity with strong risk, maneuverability and practicality, which is a commodity transaction across national boundaries between different countries. The two sides are far apart from each other. There are common rules and strict standards in all aspects of cross-border e-commerce, and every link is hidden in fraud. It is very difficult for students to master the standards and rules in classroom teaching. Without practical experience, it is easy to fall into the soft trap of cross-border e-commerce fraud. Therefore, strengthening the experiment and practical teaching is the only way to train the English professionals of cross-border e-commerce for import and export enterprises. It plays an important role in the cultivation of innovative talents of applied cross-border e-commerce English majors ${ }^{[15]}$. 
Students may, through simulated experimental teaching at school, outside school practice and practical training, lectures on outstanding entrepreneurs, engage in e-commerce activities directly, be familiar with cross-border e-commerce, import and export business, foreign trade correspondence and telecommunications, etc. In order to shorten the distance between the theory and practice of cross-border e-commerce, improve the management of foreign trade. Contact with "working position" in advance, familiarize with the work flow, also enhance the pertinence and effectiveness of students' study, shorten the blind exploration process and unsuitable process of students' employment in the future. In addition, in the allocation of hours of credit, the undergraduate major of cross-border e-commerce English in independent colleges should pay more attention to learning training and highlight practical links in teaching, such as social practice, cognitive practice and social investigation in every academic year and semester. Focus on training students skilled foreign trade skills and the ability to solve practical business problems.

\subsection{To establish a contingent of teachers with the ability of professional innovation}

The qualified teachers are cultivated who can meet the needs of the society and train applied and innovative talents, and form an academic team based on the implementation of cultural quality education. A large number of practical ability or management experience of the "technician" teachers as the backbone of the team. For example, "Foreign Trade document practice" is a professional course for cross-border E-commerce, which is characterized by strong professionalism, strong practical operation, and so on. It is embodied in specific, practical business, such as how to examine letters of credit. How to prepare the relevant documents under the L / C, the order in which the documents are prepared, the main points in the preparation process, etc. Moreover, the content of the course is to reflect the actual work of the actual bill and its circulation situation, its operation requires intuitive teaching method. The teacher of this course should make use of all kinds of document styles and operate while speaking, so that abstract knowledge can be transformed into concrete and intuitive operation. In the introduction of each kind of document, it is necessary for the teacher not only to have a theoretical foundation, but also to emphasize the practical operation ability. Therefore, the cross-border e-commerce English specialty training reflects the construction of teachers with applied ability.

\section{Discussion and Prospect}

In summary, the independent college, which aims at cultivating applied and innovative talents, must adapt to the needs of economic development and the establishment of a harmonious socialist society. In the training of English majors in cross-border e-commerce, it is necessary to "educate people" and "educate talents". The combination of brain use and practical work not only puts emphasis on intellectual education and moral education, but also on theory and practice, on knowledge, on quality and ability, on showing distinct characteristics of the times and on the training requirements of applied innovative talents. In constructing the training objectives, first, as in the case of academic undergraduate elite education, students majoring in cross-border e-commerce English should be trained in basic theories, basic knowledge and basic skills, with emphasis on teaching students knowledge and abilities of lifelong use. Improve students' ability to apply knowledge and develop and innovate technology. Theory is the basis of application, and application is the process in which theory is seen in practice. Therefore, the applied creative talents of cross-border e-commerce do not ignore the learning of theoretical knowledge, but take the theoretical basis of certain economic and cross-border e-commerce English as the premise. Under the "thick foundation, heavy application" training model, we can learn well, apply the existing scientific research results in the field of cross-border e-commerce to the practical work of foreign 
trade in accordance with the operational procedures we have learned, and be able to apply them to the actual work of foreign trade under changed circumstances. Solve new problems creatively according to learned theory and operation skills and creatively improve work efficiency. Second, based on the characteristic undergraduate education, we should train all kinds of applied creative talents needed for development, and cultivate students with strong social activities, cooperation and communication ability, practical operation ability under the premise of having better cultural quality. Cross-border e-commerce activities involve domestic and foreign banks, customs, shipping companies and other aspects of departmental cooperation, cross-border e-commerce traders must pay attention to all aspects of communication and cooperation. Therefore, foreign trade operators are required to have good psychological quality, team consciousness, it is able to undertake foreign trade business, coordinate various business links and coordinate multi-party relations. Third, we must take the market as the premise, take the employment as the guidance, trains the applied innovation talented person which adapts to the foreign trade front line work. Therefore, in the direction of personnel training, we should give full consideration to the needs of the society for the talents of cross-border electricity businessmen, pay attention to improving the students' learning ability, employment ability, turnover ability and entrepreneurial ability, so as to enhance the employment competitiveness in an all-round way.

\section{References}

[1] Bai Yingcai. A probe into the Reform of College English Teaching in Art Colleges and Universities under the background of Mousing course [J]. Journal of Kaifeng Institute of Education, 2015(9):41-42.

[2] Chen Bingbing. MOOCS Curriculum Model: contribution and Dilemma [J]. Foreign language Audio-Visual Teaching, 2014(3): 39-40

[3] Hu Tiesheng. Micro class: the new situation of the development of regional educational resources [J]. Audio-visual Education Research, 2011(10): 62.

[4] Xue Jingying, Ni Xiaoyong. On the Reform of College English Teaching under the trend of Educational Informatization[J]. Integration of Information Technology and Teaching practice, 2015(12): 43-45.

[5] Zheng Bifang, Gu Xufei. Walk through the "Cloud" end of practical Education Information--On the Application of Cloud platform in English Teaching [J]. Education and Teaching Forum 2016(03): 263-265.

[6] Li Gang. Reform of English Teaching methods under the background of Informatization [J]. Campus English, 2015(06): 185.

[7] HAN Dezhi, CHEN Xuguang, LEI Yuxin, DAI Yongtao, ZHANG Xiao. Real-time data analysis system based on Spark Streaming and its application. Journal of Computer Applications, 2017, 37(5): 1263-1269.

[8] SUN D W, ZHANG G Y, ZHENG W M. Big data stream computing: technologies and instances[J]. Journal of Software, 2014,25(4):839-862.

[9] HAO S G, ZHANG L, and MUHAMMAD G. A union authentication protocol of cross-domain based on bilinear pairing [J]. Journal of Software, 2013, 8(5): 1094-1100.

[10] MA Youzhong, ZHANG Zhihui, LIN Chunjie. Research progress in similarity join query of big data. Journal of Computer Applications, 2018, 38(4): 978-986.

[11] PANG J, GU Y, XU J, et al. Research advance on similarity join queries[J]. Journal of Frontiers of Computer Science \& Technology, 2013, 7(1):1-13.

[12] SHEN Wei,WYNTER L.A New One-level Convex Optimization Approach for Estimating Origin-destination Demand [J].Transportation Research Part B: Methodological,2012,46(10): 1535-1555.

[13] ZIHAYAT M,AN A.Mining top-k high utility patterns over data streams[J].Information Sciences,2014,285:138-161. [14] YUN U,RYANG H,RYU K H.High utility itemset mining with techniques for reducing overestimated utilities and pruning candidates[J].Expert Systems with Applications,2014,41(8):3861-3878.

[15] MIORANDI D,SICARI S,PELLEGRINI F D,et al. Internet of things: vision, applications and research challenges[J]. Ad Hoc Networks,2012,10(7):1497-1516. 